\title{
En människa bland andra?
}

\author{
Äldre människors begripliggörande av vardagen under \\ covid-19-krisen
}

\section{A person among others? Older people's understandings of their everyday life during the Covid-19 crisis}

This article examines how older people make sense of their situation in calls to a helpline a few months into the Covid-19 pandemic. By drawing on the sociology of everyday life to analyse callers' various understandings of the crisis, the article nuances current knowledge about older people's situation. The thematic analysis shows that the callers make sense of the crisis linked to social relations on a personal, anonymous, and abstract level. The callers' responses to challenges to their everyday routines - adjustment or critical evaluation - are connected to different approaches to trust: basic trust in a shared social reality with someone or regulating trust in a set of norms independent from that other. Whereas the calls demonstrate very few positive adjustments in personal relations, they show that anonymous and abstract relations serve as important resources for both maintaining and re-evaluating everyday life during a crisis. Although older people's lack of secure personal relations during the pandemic points to vulnerability, their resourcefulness is apparent in their active engagement in important anonymous and abstract relations.

Keywords: Covid-19, crisis, older people, the sociology of everyday life, trust

EN KRIS INNEBÄR ett hot mot en rådande ordning och även om kriser kan äga rum på individ-, grupp- eller samhällsnivå så förstås de alltid av individer i samspel med andra (De Rycker \& Mohd Don 2013). Då kriser är oväntade och därför kännetecknas av osäkerhet finns det rum för olika tolkningar och handlingsalternativ (Nevile 2013; Schatzki 2016). Covid-19-pandemin är ett typexempel som visar hur en övergripande beskrivning av pandemin som ett yttre hot i form av ett virus som skadar organismer möter flera konkurrerande beskrivningar om vilken ordning som egentligen hotas och på vilket sätt hotet bör hanteras. Sociologer har efterlyst analyser av hur covid19-pandemin kan förstås som en kris i hur människor lever sina vardagliga liv (Giustini 2020). Att undersöka hur vardagen i krisen begripliggörs av äldre människor är speciellt viktigt eftersom denna grupp - som riskgrupp - berörs specifikt av både smitta och restriktioner (Armitage \& Nellums 2020; Leung 2020). 
Denna artikel ger kunskap om covid-19-pandemins betydelse för äldre människor genom att utifrån ett vardagssociologiskt ramverk (Garfinkel 1967; Mead 1981a; Sacks 1989; Schatzki 2016; Scott 2018) undersöka samtal till telefonlinjen Äldrelinjen. Äldrelinjen är en telefonlinje som erbjuder samtal till personer över 65 år i behov av medmänskligt stöd. Äldrelinjen drivs av den ideella föreningen Mind. Samtalen till Äldrelinjen har ökat markant under coronakrisen. Volontärerna som arbetar på linjen är sällan experter utan ofta själva äldre personer som vill lägga sin tid på att stödja andra. Vardaglig kontakt med "främlingar" har lyfts fram som en betydande motvikt till social isolering hos äldre (Fingerman 2009; Torres 2019). Telefonlinjer kan förstås som en resurs för sådana möten i vardagen när den fysiska distanseringen i och med covid-19-pandemin hindrar människor från att ses på andra sätt. Volontärerna på Äldrelinjen fungerar i detta avseende som samtalspartners för de äldre inringarna när de ska förhålla sig till vardagens nya villkor.

Ett dussin studier som använder vardagssociologiska begrepp för att studera socialt samspel i krissammanhang har för vitt skilda områden, såsom Kubakrisen 1962 eller finanskrisen 2008, visat hur avgörande delar av en kris upptakt och hantering handlar om begripliggörande (Gibson 2011; Svetlova 2012). Studierna visar hur organisatoriska samt tids- och samspelsmässiga ramar samverkar när skeenden ges mening. Vardagssociologiska krisstudier har hittills fokuserat på hur människor i samspel hanterar akuta problem, till exempel hur soldater förstår fordon som antingen bundsförvanter eller fiender (Nevile 2013) eller hur yrkesutövare, såsom poliser, förhandlar med någon som hotar att avsluta sitt liv (Clifton 2015; Sikveland, Kevoe-Feldman \& Stokoe 2019; Iversen 2019). Hur kriser begripliggörs och hanteras i människors vardagsliv är dock ett mindre studerat ämne (Schatzki 2016).

Artikelns syfte är att undersöka hur äldre personer begripliggör krisen i förhållande till sina vardagsliv. Genom att fokusera på begripliggörande i vardagen, snarare än yrkesverksammas förhandlingar och beslut i skarpt läge, bidrar vi med en ny vinkel till detta begränsade men växande fält av vardagssociologiska krisstudier. Vårt huvudbidrag är dock empiriskt - det bidrar till forskningen om äldre och åldrande under covid-19-pandemin. Genom att studera naturligt förekommande diskussioner om krisens betydelser utifrån ett vardagssociologiskt ramverk ger artikeln ny kunskap om olika sätt på vilka äldre förstår sin situation. Denna kunskap är viktig: dels ger den en inblick i en ännu outforskad stödverksamhet som når äldre i krisen, dels nyanserar den kunskapen om äldres situation under covid-19-pandemin.

\section{Äldre människors situation under covid-19-pandemin}

Tidigare pandemiska kriser, som SARS-utbrottet 2003, har medfört en ökad grad av psykisk ohälsa (Chan, Chiu, Lam m.fl. 2006; Mak, Chu, Pan m.fl. 2009; Yip, Cheung, Chau m.fl. 2010) och covid-19-pandemin riskerar att utlösa liknande problem (Cullen, Gulati \& Kelly 2020; Sher 2020; Xiang, Yang, Li m.fl. 2020). Under covid19-pandemin har äldre personer globalt pekats ut som en riskgrupp, både medicinskt (Leung 2020; Liu, Chen, Lin m.fl. 2020) och socialt (Armitage \& Nellums 2020). 
En enkätstudie ( $\mathrm{n}=52$ 730) i Kina om äldres psykologiska välbefinnande under covid19-pandemin visar att 35 procent upplever oro (Qiu, Shen, Zhao m.fl. 2020; se också Meng, Xu, Dai m.fl. 2020). Högst nivåer av oro återfinns i åldersspannet 18-30 år samt hos personer som är 60 år och äldre. Även Folkhälsomyndighetens (2020b; se även 2020a) studie ( $\mathrm{n}=1$ 602) visar att personer över 60 år oftare än andra uppger oro för att själva bli sjuka.

Gerontologer har vidare observerat en ökad ålderism under pandemin och menar att medier, politiker och forskare beskriver människor över 70 år som en homogen grupp av ömtåliga och hjälplösa människor som inte bidrar till samhället (Ayalon, Chasteen, Diehl m.fl. 2020; Rahman \& Jahan 2020). När ålder lyfts fram som en kritisk variabel går det emot berättelser om hur vi alla står enade i krisen. Att ålder är en faktor som vägs in vid resursfördelning i vården riskerar att förstärka klyftan mellan yngre och äldre (Le Couteur, Anderson \& Newman 2020). Forskare har alltså lyft fram äldres utsatthet gällande psykisk ohälsa men också utsattheten för stereotypiskt bemötande.

Det finns dock studier som pekar på att äldre inte nödvändigtvis är den mest utsatta gruppen under krisen när det gäller psykisk ohälsa. Även om äldre personer upplever ökad oro finns det studier som visar att yngre i högre grad drabbas av psykiska besvär (Folkhälsomyndigheten 2020a). En enkätstudie i Spanien (Losada-Baltar, JiménezGonzalo, Gallego-Alberto m.fl. 2020) under mars 2020 visar att äldre människor med positiv syn på sitt åldrande är mer motståndskraftiga mot psykologiska effekter av pandemin, jämfört med yngre människor. En svensk enkätstudie som berör upplevelser av oro och välmående över de senaste fem åren (Kivi, Hansson \& Bjälkebring 2020) visar också att äldres nivåer av självrapporterad oro generellt inte har ökat under covid-19-pandemin jämfört med tidigare år. Forskarna argumenterar för att den fysiska distanseringen kan dämpa oron bland de äldre eftersom den reducerar risken för smitta.

Flera studier lyfter dock fram att en liten grupp av äldre personer far särskilt illa under krisen (Qui, Shen, Zhao m.fl. 2020). De som oroade sig mer för negativa hälsoeffekter och ekonomiska konsekvenser av krisen rapporterade exempelvis ett lägre välbefinnande än genomsnittet (Kivi, Hansson \& Bjälkebring 2020). Även om försiktighet behövs vid tolkningen av resultat över nationsgränser, eftersom olika länder har bemött pandemin på olika sätt, finns det alltså en genomgående beskrivning av äldres utsatthet i tidigare forskning. Det finns också studier som visar att krisen förstärker ojämlikhet: äldre som haft det relativt bra innan krisen klarar sig bättre medan de som var utsatta innan krisen verkar drabbas hårdare. Enkätstudierna synliggör behovet av att kontextualisera bilden av vad det innebär att vara äldre under krisen, vilket kvalitativa studier av hur äldre personer förstår och hanterar sin situation kan bidra med. Kvalitativt orienterade studier har hittills främst fokuserat på vårdgivares situation under krisen (Jia, Chen, Xiao m.fl. 2020; Sun, Wei, Shi m.fl. 2020). En av de få kvalitativa studier som antar ett medborgarperspektiv baseras på elva australiensiska covid-19-patienters upplevelser av att leva i isolering (Shaban, Nahidi, Sotomayor-Castillo m.fl. 2020). Studien uppmärksammar inte äldres perspektiv men belyser hur patienter kan ha behov av att reflektera över och 
förhålla sig till sociala relationer, familj och lokal gemenskap, såväl som till den massmediala bilden av pandemin.

Det finns sammantaget ett stort behov av kunskap om äldres specifika situation under covid-19-krisen som samtidigt uppmärksammar olika slags utsatthet eller förståelser av att vara äldre i krisen. Den föreliggande studien bidrar till forskningen med kunskap om hur äldre personer som söker socialt stöd begripliggör sina vardagsliv i krisen. Artikeln belyser olika sätt att förhålla sig till covid-19-krisen och erbjuder därmed en nyansering och fördjupning av tidigare forskning om äldres situation.

\section{Vardagssociologisk teori}

I denna artikel synliggör vi vardagens betydelse på två sätt: dels empiriskt då vi undersöker hur människor i samtal skapar mening runt ett vardagsliv i krisen, dels teoretiskt då vi fokuserar på (om)skapandet av social ordning som något människor gör i sitt vardagsliv. Sociologin är den disciplin framför andra som har betonat vardagens betydelse för produktion och reproduktion av social ordning. Vardagssociologer menar att människor upprätthåller social ordning genom rutiniserade handlingar i sina dagliga liv. Garfinkel (1967) undersökte till exempel hur människor aktivt samkonstruerar social ordning i förhållande till lokala mål, en för situationen fungerande definition av vad som pågår. Garfinkel fokuserar på relationen mellan en förklarbar (accountable) social ordning och rutiniserade handlingar, så kallade etnometoder (Garfinkel 1967:252). Att regelbundet gå till affären eller ta hand om posten är sådana enkla metoder som bidrar till att organisera människor som delar av en gemenskap (jfr Sacks 1989). Mead (1981a:127) menar i ett liknande resonemang att i många vardagliga situationer har rutiniserade handlingar blivit så vanemässiga att det inte krävs någon reflektion för att utföra dem.

En kris som får konsekvenser för människors vanemässiga handlande kan ses som ett naturligt störningsexperiment (jfr Garfinkel 1967:47) som synliggör det sedda men ouppmärksammade - de normer som annars tas för givna. Att inte kunna gå till affären innebär förutom avsaknaden av inköpta varor även en förlust av rutin. Scott (2018) påtalar att ett uppmärksammande av den vardag där "ingenting särskilt" händer låter oss studera hur icke-görande, icke-varande och icke-närvaro är det som synliggör varandet. Frånvaro, brist och tomhet utgör uttryck för en frånkoppling från det som borde finnas och synliggör därmed normer (Scott 2018). När det vanemässiga handlandet hejdas, påpekar Mead (1981b:341), innebär det en störning som tvingar oss att bli aktivt medvetna om vanorna som vi fört med oss in i situationen, vilket kan leda till ett ifrågasättande av vanor och normer. Motstridigheten kan få till följd att individen börjar omvärdera aspekter av sitt liv som upplevs problematiska (jfr Lundin 2004; Persson \& Thunman 2011). Schatzki (2016) påpekar dock att en kris inte nödvändigtvis leder till reflektion: för det mesta anpassar vi vårt handlande till den nya situationen, utan att närmare ifrågasätta våra vanor eller de normer som gör våra handlingar förklarbara.

För att förstå hur det kommer sig att kriser ibland leder till ifrågasättande och annars 
till anpassning kan vi använda Garfinkels begrepp om tillit. Garfinkel (2006[1963]; Watson 2009) lyfter fram två aspekter av tillit i relation till en förklarbar social ordning. Först och främst finns vad vi kan kalla en basal tillit (jfr constituitive expectancies, Garfinkel 2006[1963]:370) till en delad verklighet: tilliten till att handlingar och objekt har samma betydelse för alla deltagare i interaktion. Denna tillit handlar alltså om att människor förväntar sig att deras definitioner av situationen delas av andra kompetenta deltagare. Etnometoder bygger på, och bygger upp, denna tillit (Garfinkel 1967). När människor stöter på problem i förhållande till den basala tilliten, såsom missförstånd, hanterar de i regel detta genom anpassningar, rättelser och förhandlingar (Garfinkel 2006[1963]:376; Garfinkel 1988): när vi blir hindrade på vår dagliga promenad av en trafikolycka tar vi kanske en annan väg utan att närmare grunna på promenadens förutsättningar (jfr Schatzki 2016).

Kriser i vardagen kan dock också leda till ett brott i tilliten till att andra människor och världen fungerar på ett för oss förklarbart sätt: vi kan i exemplet ovan börja ifrågasätta den organisering av trafiken som tillåter en olycka. När villkor för basal tillit inte uppfylls kan sociala aktörer inte ta för givet att de handlar enligt gemensamma normer (Garfinkel 2006[1963]:375). Då vänder sig människor till reglerande normer (jfr regulative rules, Watson 2009:483), vad som kan kallas en reglerande tillit. Reglerande tillit innebär att människor försöker förklara andras beteende enligt normer som är externa i förhållande till mål i den aktuella situationen. Personer avfärdar sina medaktörers beteende som avvikande, till exempel som respektlöst eller bortskämt, och förlitar sig alltså inte på möjligheten att etablera eller justera en gemensam definition i själva relationen (Garfinkel 2006[1963]:375). Här kan vi alltså tala om att krisen ger upphov till ifrågasättande.

De flesta människor litar på att världen är förklarlig och att andra kommer att förstå vad de menar. Därmed uppmärksammar de inte verkligheten som en social konstruktion utan hanterar problem genom rättelser och anpassning. Garfinkel påpekar dock att personer i utsatta positioner kan ha en särskild känslighet för det arbete som krävs för att verkligheten ska upplevas som stabil, och en brist på basal tillit till det självklara i de egna upplevelserna (Garfinkel 1967:183; Turowetz \& Warfield Rawls 2020). Ett exempel ges i Sacks (1989) analys av samtal till ett centrum för suicidprevention i Los Angeles, i vilken han beskriver samtal från änkor och änklingar som hävdade att tiden tynger dem eftersom ingenting längre händer. Sacks menar att denna typ av uttalanden kan förstås i förhållande till människors (etno)metoder för att hantera normer om mänskligt värde. En metod med vars hjälp individer fastställer sin relevans kallar Sacks (1989:266) för privata kalendrar. Genom att ordna händelser i förhållande till signifikanta andra, oavsett om det rör sig om händelser som inbegriper dessa signifikanta andra eller mer allmänna händelser i världen, ger människor dessa händelser en specifik mening. Till exempel kan statsministerns död kopplas till det år då ett par förlovat sig. En viktig skillnad mellan privata kalendrar och den allmänna kalendern (everybody's calendar; Sacks 1989:267), alltså ett samhälles ordnande av händelser i tid, är att privata kalendrar inte har en given kontinuitet. Den allmänna kalendern fortsätter i en obestämbar framtid men en privat kalender avslutas när ett särskilt vi 
avslutas. Medan ett normskifte vid en sådan kris - förlusten av ett vi - handlar om att ifrågasätta den egna existensens relevans, skulle en anpassning kunna vara att ansluta sig till den allmänna kalendern. Kriser i människors vardagsliv kan på detta sätt kopplas till sociala relationer: deras koppling till makar, vänner, bekanta och offentliga personer är också en koppling till social ordning.

Genom att använda oss av ett vardagssociologiskt raster på en empirisk verklighet som kännetecknas av kris och utsatthet kan vi synliggöra krisens betydelse för social ordning - på vilket sätt människor i sina vardagsliv förhåller sig till en pågående kris - och hur krisen genom att introducera tomhet och icke-varande - ett frånsteg från hur det brukar eller borde vara - ruckar på tillit och synliggör social ordning (Scott 2018). Vardagssociologin låter oss alltså se vardagens betydelse för att skapa social ordning samt metoder med vilka äldre människor arbetar för att upprätthålla och/ eller omvärdera sina vardagsliv och sociala relationer.

\section{Metod}

Genom att undersöka hur vardagslivet i kris begripliggörs av inringare till Äldrelinjen kan vi se vad äldre själva behandlar som meningsfullt i ett samtal med en medmänniska. Naturligt förekommande interaktion är ett underanvänt material för att få kunskap om hur sociala problem konstrueras och hanteras; det kan ge en unik insikt i de problem som behandlas som särskilt viktiga eller svåra i en specifik kontext (Potter 2002; se vidare Flinkfeldt 2020).

Under 2019 tog Äldrelinjen emot 4100 samtal, men mängden samtal har ökat med covid-19-pandemin och bara i augusti 2020 inkom över 8000 samtal, varav cirka 1 800 ledde till kontakt med en volontär. Under våren och sommaren 2020 rekryterade Äldrelinjen 250 nya volontärer för att möta denna ökade efterfrågan och telefonnumret fick omfattande spridning i medier. 108 samtal till Äldrelinjen spelades in mellan slutet av juni och början av augusti 2020. Inget urval skedde utan alla samtal spelades in i de fall då både volontärer och inringare samtyckte. Volontärernas samtycke var skriftligt och skedde efter att de givits utförlig information om studien, medan inringarna samtyckte till deltagande i studien genom knappval innan de kopplades fram till en volontär. Den kortfattade information om studien som gavs i form av ett talsvar kompletterades genom att inringaren gavs möjlighet att ta del av skriftlig information på projektets hemsida (www.samtalsforskning.se). Insamling och analys av samtalen har godkänts av Etikprövningsmyndigheten (Dnr 2020-01808).

Eftersom inringarna är anonyma är bakgrundsdata för dem som samtyckte respektive nekade till att delta i studien inte tillgängliga. Genom att undersöka en telefonlinje som särskilt riktar sig till äldre i behov av socialt stöd kan vi anta att studien inkluderar äldre som själva identifierat sig som i behov av medmänskligt stöd. Av de 108 inspelade samtalen nämndes covid-19 eller pandemin åtminstone någon gång i 64 av samtalen, vilket motsvarade strax under 25 timmar ljuddata. Medellängd på samtalen som berörde covid-19 var 23 minuter. Av de inringare som sa sin ålder var merparten över 70 år. Det finns inga demografiska studier av telefonlinjer för äldre personer, men studier 
av andra telefonlinjer visar en lägre förekomst av samtal från män, äldre personer, personer i etniska minoritetsgrupper och personer med lägre socioekonomisk status (Cook, Randhawa, Large m.fl. 2013). Personer som använder stödlinjer regelbundet har ofta psykiska problem eller andra svårigheter (Pirkis, Middleton, Bassilios m.fl. 2016). Vår studie stämmer överens med tidigare forskning på så sätt att kvinnor är överrepresenterade i samtalen (83 procent av inringarna var kvinnor) och genom att återkommande inringare berättar om svåra livsupplevelser. Nästa alla som ringde talade också svenska utan någon brytning. Utifrån de personliga detaljer som inringarna gav om sina liv framgår dock att det fanns en spridning i socioekonomisk bakgrund. Studien behandlar alltså samtal med äldre personer, i många fall kvinnor med svenska som modersmål, som både upplever behov av att prata med någon utomstående och som sedan initierar en sådan kontakt.

Samtalen som rörde covid-19 analyserades genom en induktiv, kvalitativ analys i flera steg, som efter hand ledde fram till distinkta kategorier och så småningom teman. Tematisk analys är en deskriptiv, kvalitativ metod för att identifiera, analysera och på ett nyanserat sätt rapportera mönster i ett material (Braun \& Clarke 2006; Vaismoradi, Turunen, Bondas m.fl. 2013). Vi har utgått från empirin och sedan diskuterat vilka begrepp som behövs för att förklara och nyansera empiriska teman. Tidigt $\mathrm{i}$ analysprocessen framstod dels vardag och dels sociala relationer som centrala teman. Samtalen kodades genom att de relationer (till exempel till barn, släktingar, grannar, djur, arbetskamrater, organisationer, offentliga personer) som diskuterades markerades, tillsammans med en kort anteckning om hur relationen aktualiserades i samtalet (till exempel som stöd, brist, källa till oro). Vi grupperade relationerna efter betydelsen de gavs i samtalen (personliga relationer, anonyma relationer, abstrakta relationer). I samspel med utveckling och diskussion av teman prövade vi teoretiska begrepp som kunde fördjupa förståelsen av empiriska teman. Vardagssociologin blev tidigt en del i denna process, medan begrepp om tillit inkluderades först när det blev tydligt att krisen för inringarna hängde ihop med just tillit i relationer.

Genom hela analysprocessen har kodningsstrukturen återkommande diskuterats och utvärderats, i enlighet med Braun och Clarkes (2006:91) rekommendation att data inom teman ska hänga samman på ett meningsfullt sätt, samtidigt som det ska finnas tydliga drag som gör det möjligt att särskilja identifierade teman från varandra. I ett avslutande steg har analysen validerats genom en workshop med volontärer på Äldrelinjen där resultaten diskuterades och volontärerna uttryckte samförstånd kring slutsatserna (jfr Creswell \& Miller 2000). En viktig poäng med volontärernas validering var att se om temana i de samtal vi spelat in verkade skilja sig mot andra samtal på linjen (från de som valde att inte bli inspelade) vilket alltså inte var fallet. I de citat som vi använder i artikeln har vi exkluderat personuppgifter och annan information som skulle kunna avslöja vem personen är. 


\section{Analys: Vardagens slut}

Ett återkommande tema som genomsyrar samtalen är vardagens slut - inringarna beskriver hur många aspekter av vardagen som de vanligtvis tar för givet har gått om intet eller hur problem i deras vardagsliv har accentuerats. De kan inte handla, gå ut på promenad eller träffa personer såsom de tidigare gjort. Gruppen äldre är dock heterogen - att hålla fysisk distans utan total isolering kan vara svårt för någon som är beroende av andra för att ta sig fram medan den som kan röra sig fritt och har många bekanta kanske har lättare att hantera nya villkor för umgänge. En ytterlighet exemplifieras i nedanstående samtalsutdrag, då inringaren beskriver krisen som en förlust av allt som gör livet värt att leva:

Inringare: Fram till detta jobbade jag, åkte till föräldrar, träffade barn och barnbarn, nu är allt borta.

Volontär: Svår omställning.

Inringare: I början gick det väl an men nu känns det som att det här tar livet av mig. (EL2440)

Nuet i krisen beskrivs i kontrast mot hur livet tidigare fortgått och avsaknaden av rutiner för att upprätthålla relationer till arbete och närstående begripliggörs som att även själva relationerna försvunnit. Krisen uppenbarar på så sätt det tidigare ”sedda men ouppmärksammade" handlandet (Garfinkel 1967:47): störningen av vardagen framhäver en social ordning. Volontären antyder försiktigt omställningen till en ny vardag - en möjlighet till anpassning (Schatzki 2016) - men inringaren beskriver vardagen i krisen som outhärdlig i längden.

Ett helt annorlunda förhållningssätt exemplifieras i följande utdrag då en inringare beskriver störningen av vardagen som en positiv väckarklocka: "jag tror människor egentligen i grund och botten tycker om små saker. Och jag tror inte det första man tänker på är att resa utan jag tror att man tänker 'Hur har jag det i mitt vardagsliv?’”. Volontären håller med och svarar att "en del blir nästan lite chockade av att dom inte kan göra som dom alltid har gjort och så tänker jag det är nyttigt att börja fundera på varför jag alltid gör som jag gör.” (EL2486). Här begripliggörs inte krisen i termer av förlust av de nödvändiga relationerna; det blir i stället onyttigheter såsom resor som ersätts av tankar på vad som verkligen betyder något (jfr Mead 1981b; Persson \& Thunman 2011). Exemplen visar extremfall av sätt att förhålla sig till den förlorade vardagen: som den enda ordningen som gör livet värt att leva eller som ersättbar med något potentiellt bättre.

I vår analys i följande tre avsnitt visar vi hur inringarna beskriver problem i krisen kopplat till olika former av relationer och olika etnometoder för att hantera problemen. Deras beskrivningar kan kopplas till olika förhållningssätt till basal och reglerande tillit (se Tabell 1). 
Tabell 1. Krisens betydelse för tillit i sociala relationer

\begin{tabular}{lllll} 
Relation & Kris & Etnometoder & Basal tillit & Reglerande tillit \\
\hline Personlig & $\begin{array}{l}\text { Frånvaro, } \\
\text { oro, skuld, } \\
\text { besvikelse }\end{array}$ & $\begin{array}{l}\text { Bedöma den } \\
\text { andra, avvisa } \\
\text { kontakter }\end{array}$ & $\begin{array}{l}\text { Anpassa, } \\
\text { pröva }\end{array}$ & $\begin{array}{l}\text { Extern part, } \\
\text { reducera }\end{array}$ \\
Anonym & $\begin{array}{l}\text { Frånvaro, } \\
\text { osäkerhet, } \\
\text { besvikelse }\end{array}$ & $\begin{array}{l}\text { Göra sig sedd, } \\
\text { allmän kalender }\end{array}$ & $\begin{array}{l}\text { Anpassa, } \\
\text { pröva, } \\
\text { ersätta }\end{array}$ & Reducera \\
Abstrakt & $\begin{array}{l}\text { Närvaro, } \\
\text { frånvaro, } \\
\text { vanmakt }\end{array}$ & $\begin{array}{l}\text { Nytt "vi", } \\
\text { allmän kalender }\end{array}$ & $\begin{array}{l}\text { Anpassa, } \\
\text { förhandla }\end{array}$ & $\begin{array}{l}\text { Nytt perspektiv, } \\
\text { "vi” och "dom", } \\
\text { avvisa }\end{array}$ \\
\hline
\end{tabular}

När det gäller personliga relationer beskriver inringarna en brist på tillit till andras riskbedömning eller till deras ovillkorliga stöd. Även om det teoretiskt är möjligt med anpassningar i personliga relationer ersätts i dessa samtal basal tillit i personliga relationer med reglerande tillit i form av en yttre part eller avståndstagande. I förhållande till anonyma relationer - de personer som bekräftar inringarnas existens som en människa bland andra snarare än som en specifik annan - skapar krisen frånvaro när äldre inte kommer ut, men det finns många exempel på anpassningar. Krisen kan också väcka frågor om ett större "vi" och därmed ge närhet till abstrakta relationer, eller skapa ett hotande "dom". De metoder som etablerar en (ny) fungerande gemenskap i krisen handlar på det personliga planet om att gå utanför relationen för att hitta stöd som tillåter sorg och ångest, på ett anonymt plan om säkra möjligheter att möta andra som bekräftar ens vardagliga existens, och på ett abstrakt plan om att se sig själv som en del i en större meningsfull helhet. I följande tre analysavsnitt presenteras och förklaras dessa olika sätt på vilka äldre förhåller sig till nya villkor för vardagsliv i relation till personlig gemenskap, anonym gemenskap och abstrakt gemenskap.

\section{Att värdera och omvärdera närhet i personliga relationer}

Krisen kan med Garfinkel (2006[1963], 1967) ses som en störning som introducerar risk och ökade behov i personliga relationer. Snarare än att beskriva gemensamma anpassningar eller rättelser i förhållande till den andra i den nya situationen ger dock inringarna uttryck för en förlorad basal tillit. Här används Äldrelinjen som en extern part vid oenighet eller som substitut för villkorslöst stöd. Detta innebär ett reglerande förhållningssätt till närstående. Inringare ger i samtalen uttryck för oro över sin partner när denna är mindre försiktig än inringaren själv, och för att partnern ska föra med sig smittan hem: "jag är alltid orolig när han är ute och far" (EL2413). En inringare söker å andra sidan stöd från volontären i sina argument för att det går att göra en gemensam resa med en partner som vill vara mer försiktig: 
Inringare: Min fru är lite mer risk än vad jag är för hon har [en sjukdom] och vi har ju nu levt under alla konstens regler under tre, ja fyra och en halv månader ungefär.

Volontär: Mm.

Inringare: Och så föreslog jag att vi skulle göra en nån kortare resa några dar och ta in på hotell.

Volontär: Mm.

Inringare: Och då har vi lite delade meningar där hustrun och jag, jag menar ju på att det borde rimligen inte vara så allvarligt för det är ju rent och snyggt förmodligen när vi kommer till ett hotell och sen smittning jag vet ju att det är droppsmitta och det är direktkontakt och så vidare. Hur skulle du bedöma det med att bo på hotell, är det nån risk med det tror du? (EL2442)

Ibland, som här, uppstår etiska diskussioner: hur mycket bör en människa isolera sig för sin partners skull, och kan en person kräva av sin partner att isolera sig? Vi har inte stött på några beskrivningar av positiva förändringar i relationer kopplat till ett sådant synliggörande; att tala om olika ståndpunkter skulle teoretiskt kunna leda till att relationen fördjupas, men sådana exempel finns inte i samtalen. I stället vänder sig inringare till volontären för att försöka fastställa objektiva mått för normalt respektive avvikande handlande (jfr Watson 2009).

Detta reglerande förhållningssätt gäller också vänner och grannar. I vissa av samtalen berättar inringarna om en positiv samvaro - i bostadsområdets trädgård, över villans trädgårdsstaket, eller på en promenad. Samtidigt ses grannar och vänner som en potentiell risk som inringare måste förhålla sig till (EL2481). En inringare berättar om hur hon kommit till insikt om att en granne isolerar sig i lägre grad än vad hon trott:

Inringare: Ja. Jag har en granne som jag brukar umgås med, Volontär: Mm.

Inringare: Som nu under corona så här, hon tar emot sina barnbarn och barnbarnsbarn hemma.

Volontär: Mm

Inringare: Och sen vill hon att vi ska träffas och umgås.

Volontär: Mm

Inringare: Och det törs inte jag e det fel av mej det?

[...]

Volontär: Nej det tycker jag inte, var och en måste ju handla utifrån sin känsla.

(EL2441)

Inringaren ber om ett direkt råd men frågan kan också ses som ett klagomål gällande grannens beteende. Att själv inte följa riktlinjer och sedan förvänta sig sällskap behandlas som problematiskt. Liksom i föregående exempel använder inringaren volontären för att fastställa en gemensam definition av situationen: är det fel att inte våga träffas eller, implicit, är grannens beteende förkastligt? Detta reglerande förhållningssätt till 
tillit (Watson 2009) innebär att det är inringaren och volontären som ingår en gemensam definition, inte inringaren och grannen.

Ett annat problem som inringare lyfter fram är de ökade krav som den egna nedstämdheten eller andra behov på grund av covid-19-pandemin ställer på deras personliga relationer. En inringare säger att hon är rädd att "skrämma bort" vänner eftersom hon blivit så nedstämd under pandemin. En annan inringare säger: "Jag har en kvinna som ringer varje dag och beklagar sig, bara negativt från första sekund, då tänker jag 'sån ska jag inte bli’" (EL2458). Likaså beskriver många inringare hur de inte vill belasta äldre föräldrar, barn och syskon med sina upplevelser av nedstämdhet eller ångest. En inringare säger till exempel att hon inte träffar sina barn och barnbarn alls under pandemin: "Just nu så vill jag inte att de ska se hur eländig jag är" (EL2439) och en annan berättar att hon undviker all form av kontakt sedan hon under pandemin blivit allt mer nedstämd:

Volontär: Men det är inte så här att någon av [dina barn] vet om hur du känner?

Inringare: Nej jag vill inte prata med dom.

Volontär: Du vill inte prata med dom.

Inringare: Då börjar jag låta ledsen. [börjar gråta]

Volontär: Och då vill inte du att dom ska höra det.

Inringare: Nej jag vill inte störa dom med det. (EL2482)

Inringare förhåller sig på detta sätt till en oönskad kategori av människor som bara bekymrar sig och klagar. Vi vet inte om inringarnas närstående verkligen skulle avvisa dem, men ett sådant avvisande ingår i inringarnas begripliggörande av sin situation under krisen. Därmed skapar, uppenbarar eller förvärrar krisen en upplevelse av att inte ha en självklar rättighet att bli omhändertagen: att bli förstådd som en fullständig människa i sin nöd.

Upplevelsen av att inte kunna förlita sig på andra gäller också mer praktiska saker. Medan vissa inringare beskriver barn som handlar och går ärenden är en återkommande kommentar att barn och barnbarn har sina liv och att det är svårt att be om mer när det samtidigt blivit svårare att ses. Det kan finnas vilja att hjälpa till men krisen kan också uppenbara hur äldre står ensamma:

Inringare: Ja och dom var väl två gånger och handlade och sen såg jag "nä dom orkar inte, dom tycker inte att det här e kul” så det, nä.

[...]

Inringare: Men alltså, man kan inte räkna med barn såna här gånger, man kan inte det. Och jag förstår det, dom har jobb och barn och hem, dom hinner inte, orkar inte. (EL2480)

Inringaren behandlar här barnens brist på stöd som normalt, samtidigt som deras oförmåga att hjälpa framstår som en besvikelse - ett normativt antagande om hur barn ska behandla sina gamla föräldrar som inte uppfylls (jfr Scott 2018). När inringarnas 
ökade behov inte tillgodoses av närstående uppenbaras omsorgens begränsade räckvidd. Som med olika riskbedömningar skulle ett ökat behov teoretiskt kunna mötas av ökad omsorg, och kanske ökad närhet, men detta visar inte samtalen. I stället innebär ökade behov ökad distans.

Ett liv i isolering betyder också att det finns få orsaker att ta kontakt med andra - det finns inga aktiviteter att planera och inga roliga händelser att dela med andra. Som i analysens inledande avsnitt beskrivs återkommande en tomhet eller hur "allt" har försvunnit. En inringare (EL2455) vill inte ta kontakt med vänner eftersom hon inte längre har något att berätta då hon håller sig isolerad och lever ett enformigt liv utan intressanta upplevelser. Denna beskrivning påminner om Sacks (1989; se även Scott 2018) analys av hur händelser i världen kopplas till våra privata relationer och hur tomhet uppstår när en nära relation avslutas. Skillnaden här är att personliga relationer äventyras när vardagliga göromål hindras. Det dagliga livet blir innehållslöst av isoleringen, till och med mindre innehållsrikt än vanlig vardag, och det blir svårt att upprätthålla ett "vi" runt en tom kalender.

Sammanfattningsvis beskriver inringare hur krisen synliggör problem i deras relationer som redan fanns före krisen. Dessutom ger krisen upphov till nya problem och konfliktytor. Det blir tydligt hur en positiv omvärdering av normer är beroende av en basal tillit till en gemensam verklighet som tillåter anpassningar till en ny situation (Garfinkel 2006[1963]; Watson 2009). Inringarna ger uttryck för en avsaknad av en sådan tillit: de kan inte lita på partnerns eller grannens riskhantering eller bemötande av deras ökade behov. I enstaka fall lyckas en volontär övertala inringare att dela sin oro och sorg med en närstående men i regel finns ett starkt motstånd mot detta. Denna problemorientering bör förstås i ljuset av att inringare kontaktar en telefonlinje för stöd och därför kan antas uppleva problem, men den ska heller inte avfärdas då den beskriver situationen för utsatta äldre som faktiskt söker stöd. I nästa avsnitt beskrivs ett problem där telefonlinjen fyller en viktig funktion: relationen till en anonym gemenskap.

\section{Förlust och omskapande av en anonym gemenskap}

Ett grundläggande problem för inringarna är att deras kontakt med anonyma andra genom krisen begränsats kraftigt. Bristen på möten utan förpliktelser kan vara särskilt svår att uthärda för äldre personer som av olika skäl saknar personliga relationer (Torres 2019). Inringare beskriver till exempel hur de saknar att röra sig bland människor på offentliga platser: stadscentrum, bibliotek, kollektivtrafiken, kaféer och muséer. Flera inringare uttrycker en oro för att röra sig utomhus över huvud taget, då en del som passerar förbi kanske inte kommer hålla rätt distans - och en del säger också att de själva tycker att det är svårt att avgöra vad som är lagom distans (EL2430). Detta speglar hur krisen stör den självklara tilliten till att egna och andras handlingar är förklarliga: handlandet i förhållande till andra kräver nu eftertanke och kan inte gå på rutin (Garfinkel 1967; Mead 1981b:341). Till skillnad mot inringarnas beskrivningar av personliga relationer finns det här dock många exempel på etnometoder som tillåter nya säkra sätt att träffa andra människor på ett anonymt plan. 
Som exempel brukar en inringare åka till mataffärens parkering för att sitta i bilen och titta på människor och beskriver sitt behov av att se och omge sig med andra människor: "för hur det än är kan man sätta sej där det är andra människor om man bara håller avstånd, att man känner att det finns fler" (EL2488). Krisens skapande av frånvaro från sådana möten kan därmed förstås som något som synliggör betydelsen av denna förgivettagna del av vardagslivet (Scott 2018). En inringare berättar hur hon trotsar sin rädsla för smitta för att kunna handla och därmed distrahera sig från ångest:

Inringare: Jag vet att jag ska inte gå till affärn men jag brukar gå på kvällen innan dom stänger då. Då spritar jag händerna, det står sprit där. Och då märker jag att jag mår mycket mycket bättre, den här sociala biten, att bara få gå till affärn och handla liksom.

Volontär: Ja visst, och säga "här är jag" och säga "hej" och säga "hej” åt en expedit. (EL2477)

Volontären lyfter här fram att det vardagliga mötet erbjuder en enkel bekräftelse av att världen fortgår och är sig lik: vi är båda här som medmänniskor och ser varandra. Att upprätthålla sådana etnometoder för ordnandet av vardagen (jfr Sacks 1989), om än med anpassningar till smittorisken (jfr Schatzki 2016), bekräftar personens existens i ett sammanhang.

En del av att ha tillgång till en anonym gemenskap handlar om möten med och inom organisationer. Inringare beskriver ibland personliga relationer med personal inom organisationer (till exempel hemtjänstpersonal eller personliga assistenter) men överlag nämns dessa som anonyma relationer - då personalen beskrivs som utbytbara samtalspartners mer än som unika och oersättliga kontakter. När kontakter med andra människor begränsas kan till exempel vårdbesök få en stor betydelse: "Livet blir ganska enformigt, nu var jag hos fotvården och det var underbart att prata med en människa” (EL2435). Liksom i föregående citat kopplas här mötet inte till en särskild annan, utan poängen är just anonymiteten. När ett sådant vardagligt möte tas ifrån oss blir dess betydelse för att vi ska känna oss som en människa bland andra tydlig. En inringare berättar till exempel om sin ensamhet och säger att hon tidigare ändå brukade ha ett visst umgänge genom att delta i kyrkans aktiviteter (EL2407). En annan inringare som i vanliga fall brukar hjälpa till som kyrkvakt berättar att sedan covid-19-pandemin är "allt borta" (EL2488). Samma bristbeskrivning finns när det gäller pensionärsorganisationer:

Inringare: Jo jag e ju med i två föreningar så att jag var ju med i en kurs men sen kom ju coronan då så att,

Volontär: Jag vet, dom tog ju bort allt.

Inringare: Ja dom tog bort allting. (EL2473)

För inringaren och volontären blir nedstängningen av den aktuella föreningsverksamheten begripliggjord som ett exempel på att allt tas bort. Sådana uttryck synliggör, 
liksom i föregående två avsnitt, det extrema i krisen - upplevelsen av en total frånvaro (Scott 2018). Med Sacks (1989) kan frånvaron förstås som en brist på tillgängliga resurser för att synliggöra den egna betydelsen. Denna brist kopplas av inringarna till ångest, tristess och ensamhet (se Scott 2018).

Hemtjänsten är en av de organisationer som nämns både som tröst och risk. När många sociala kontakter begränsas blir det vardagliga samtalet med hemtjänstpersonalen desto viktigare. En inringare berättar till exempel att hon är helt ensam, förutom de tre timmar i veckan som hemtjänsten är där (EL2482). Överlag omtalar inringare sin hemtjänstpersonal med värme. Samtidigt beskrivs hemtjänstpersonalen som stressade och utan flexibilitet som motsvarar inringarnas behov, till exempel av utevistelse: "Man måste beställa det och nu blev det dåligt väder" (EL2422). Inringare säger också att de inte släpper in hemtjänsten om de inte har skyddsutrustning och andra avbeställer hemtjänstens besök (EL2408, EL2456). På så sätt försvinner en viktig källa till social kontakt.

Inringare använder telefonlinjer, såsom Äldrelinjen, för att få tillgång till en anonym gemenskap. Dessa anonyma relationer kan ersätta de personliga: inringarna kan i princip ägna ett helt samtal åt att klaga och de behöver inte ha något intressant att förmedla eftersom viet som skapas inte förpliktar till långtgående ansvar. För många inringare är dock en slags ömsesidighet viktig då de frågar de anonyma volontärerna om deras vardag. Äldrelinjen verkar på det sättet ersätta en del av den vardagliga socialiteten med ytliga bekanta eller främlingar. Medan rädsla och oro är ett återkommande ämne är det också många samtal som behandlar helt vardagliga saker: vädret, blommor som växer i trädgården, boktips eller radioprogram. Flera inringare berättar om husdjur som ger närhet, sällskap och en anledning att gå ut, utan förpliktigande att hålla ett gott humör (jfr Redmalm 2020). Att få dela dessa saker med någon verkar kunna bli en ersättning för den uteblivna vardagen: "Jag tycker alltid att de är lite trevligt, jag brukar alltid ringa till folk och prata med nån för jag har lite ont av oro och ångest och det har man ju fått i den här coronakrisen ännu mer” (EL2481).

Eftersom samtal till telefonlinjer fungerar som en viktig metod för att inte uppslukas av oro är det förståeligt att många uttrycker frustration över att det är svårt att komma fram till Äldrelinjen och andra linjer. Svårigheten att komma fram påtalas särskilt vid helger och högtider samt måndagsmorgnar då människor kanske väntat under helgen med att ringa. Det här är tider då många människor har saker i sina kalendrar, inte minst barn och barnbarn, vilket synliggör inringarnas utsatta situation. Det kan leda till en känsla av att det dagliga livet, den allmänna kalendern (Sacks 1989), fortsätter, medan inringaren står ensam kvar. Samtidigt är de allra flesta positiva trots lång väntan. En person som ringt tolv gånger utan att få svar säger när hon äntligen får svar, "Va ja ä glad att ja kommit fram!", och skrattar.

Sammanfattningsvis beskriver inringare hur krisen skapar en påtaglig frånvaro i deras liv, där en anonym kontakt med andra tidigare bekräftat deras existens. Inringarna gör denna frånvaro ytterst påtaglig både genom att tala om besvikelser och uteblivet umgänge, och genom att berätta om de få begränsade möten de trots allt har. Vardagens slut innebär här att betydelsen av dessa anonyma relationer har synliggjorts. 
Samtalen innehåller exempel på etnometoder för att hantera tomheten eller bristen, såsom att göra sig sedd av andra genom att gå ut eller ta kontakt med serviceorganisationer och telefonlinjer. Därmed ger inringarna i många fall uttryck för en bibehållen basal tillit till sin relevans som människor i förhållande till andra anonyma människor. I det sista analysavsnittet beskrivs hur inringare på ett mer abstrakt plan föreställer sig en gemenskap.

\section{Den abstrakta gemenskapen som tröst och hot}

Krisen skapar inte bara frånvaro. Ett sätt att begripliggöra den nya situationen, som lyfts fram av både inringare och volontärer, är något som kan kallas en abstrakt gemenskap. Denna gemenskap kan utgöras av ett enat "vi" eller ett hotande "dom". Några personer pratar om "den svenska linjen", det vill säga Sveriges sätt att hantera pandemin i relation till andra länder (EL2446). En inringare säger att Anders Tegnell "är jättebra, jag är så glad att vi har honom här i Sverige" och tillägger "det vore så skönt att få visa världen att vi gjorde rätt, att barnen fick leva kvar sitt vanliga liv. Jag tror på den svenska policyn” (EL2455). På det här sättet uttrycks en samhörighet med ett svenskt "vi" i kristid (jfr Brown 2020). Volontärer lyfter också fram hur inringarna beter sig föredömligt i relation till den svenska strategin:

Inringare: Det kommer ingen hit och jag går ingenstans.

Volontär: Ja du har lytt hans råd, en av vardagshjältarna. (EL2455)

Genom att tolka inringarens beskrivning av brist på social kontakt som ett aktivt handlande i ett kollektiv av hjältar under ledning av Anders Tegnell, ger volontären här en positiv ram runt tomheten; det är att ta ansvar för en gemensam angelägenhet och inkluderar tydligt inringaren i "den svenska kampen". Att skapa en närvaro av andra som gör likadant kan jämföras med Sacks (1989) beskrivning av återförande av människor till en allmän kalender som en etnometod: vardagens slut - frånvaron av det som brukar vara - förstås som något som omfattar ett kollektiv av andra.

Relationen till en abstrakt gemenskap gäller också världen och mänskligheten i stort. Flera inringare konstaterar att pandemin drabbar alla i hela världen, vilket verkar göra situationen lite lättare att hantera. Pandemin blottar därmed ett grundläggande existentiellt villkor - en gemensam mänsklig skörhet. En inringare fördjupar en sådan diskussion om sin relation till mänskligheten och sin plats i världsalltet. Hon menar att människor visat sina bästa sidor under pandemin, hon får till exempel böcker hemkörda till sig av volontärer. Meads (1981a) idéer om hur en framtvingad reflektion över vanor kan leda till en ny definition av ens situation kan alltså tydligare appliceras på diskussioner om abstrakta gemenskaper, än på samtal om personliga och anonyma relationer. Störningen uppmärksammar en ordning av beroende och reglerande tillit i positiv bemärkelse. Inringaren säger att hon lever i dödens väntrum och har börjat reflektera över sitt eget åldrande. När hon ser sin kropp utifrån påminns hon om att hon är medlem av arten människan som sett ur ett geologiskt tidsperspektiv bara existerat en kort stund på jorden, men tillägger att "så länge solen finns så finns ju vi." (EL2418). 
Detta uttryck är en enkel, universell sanning som får en speciell betydelse i relation till den unika situation som pandemin innebär. Återkommande i samtalen använder inringare och volontärer idiomatiska uttryck med samma enkla, universella innebörd, såsom "Man får ibland försöka tänka att glaset är halvfullt snarare än att glaset är halvtomt" (EL2418), ”Friskt vågat är hälften vunnet" (EL2482), "Sånt är livet, det är det, det går upp å det går ner" (EL2481), eller "och så säger vi som vanligt folk brukar säga, gå ut och fånga dagen, det vi kan göra” (EL2486). Sådana uttryck kan förstås som en etnometod - att anspela på en gemensamt känd verklighet som finns kvar trots krisen. Därmed införlivas det okända i en delad kulturell förståelse, en basal tillit till att människor delar social verklighet (jfr Garfinkel 2006[1963], 1967). Gemenskapen synliggör att människor har tagit sig igenom svårigheter förut. Vi kommer att överleva pandemin som art, men det kommer att komma nya katastrofer. Denna förståelse innebär en anpassning till situationen genom att den kopplas till en allmän kalender, där regelbundna pressträffar och sommarprat skapar en samhällelig gemenskap medan krisens unicitet synliggör kopplingen till en mänsklig, livsloppsbetonad kalender.

För personer som berättar om motsatsen till en abstrakt gemenskap, alltså samhället som hot, framstår i stället världen och framtiden som något man exkluderas från: "Jag känner mig bortkopplad från världen helt och hållet" (EL2484). I inledningen av ett samtal tar en inringare upp hur samhället sparar pengar på att sådana som hon dör:

Inringare: Det senaste jag läste nu, det är att dom sparar in pengar i och med att det är fler och fler äldre som dör i covid.

Volontär: Jaha.

Inringare: Att regeringen sparar in pengar på oss som dör då. (EL2480)

Inringaren inkluderar sig själv i den grupp som dör och regeringen beskrivs som de som vinner ekonomiskt på detta. Senare i samma samtal beskriver inringaren sin upplevelse av att avvika från andra: "Jag e väl den enda i affärn som har munskydd tror jag". (EL2480). Här beskrivs det egna handlandet som avvikande i en fientlig värld: världen byggs upp av ett "jag" och "dom" snarare än ett "vi”. Att bära munskydd skulle kunna fungera som en metod för att identifiera sig med andra som tar ett kollektivt ansvar, men när inringaren inte ser andra göra likadant blir ansvarstagandet en avvikelse. Att vara ensam och utsatt i förhållande till en större gemenskap gör att krisen upplevs som speciellt svår. En annan inringare som menar att handtvätt och distansering inte varit något större problem beskriver ändå hur attityden i Sverige väcker känslor av ilska, ledsamhet och vanmakt:

Inringare: Men ja, till slut så tycker jag att Sverige håller på att förstöra.

Volontär: Det känns det som.

Inringare: Dom förstör ju oss. Jag har, jag känner en ilska över det här. Det är klart att ingen kan hjälpa det här, men det är någonting i attityden som gör, ja det är väl att man är ledsen också.

Volontär: Ja, ja. 
Inringare: Och jag vet inte hur man ska hålla sig glad, jag vet inte hur man ska tackla det längre. (EL2482)

Inringaren ger uttryck för en upplevelse av att vara utsatt för både risken att drabbas av corona och för en attityd i Sverige som verkar handlingsförlamande. "Sverige" blir "dom", som förstör för "oss" och inringaren sätter på så sätt sig själv utanför den större gemenskapen. Dessutom uttrycker flera inringare att det är svårt att finna gemenskap och tröst genom tillhörigheten till gruppen äldre, eftersom de äldre isoleras från varandra:

Inringare: Alla är ungefär i min ålder och alla ska akta sig, det är det här påbudet vi har fått allihop, "akta er för andra människor, blanda er inte med en massa folk". [...] Om man hör det hela tiden då tänker jag att vad tänker de här människorna, hur blir en människa om man får höra det hela tiden. (EL2482)

Inringarna som beskriver sig själva som exkluderade från en abstrakt gemenskap pekar å ena sidan på en förståelsemässig, basal brist på tillit där det svenska bemötandet av krisen framstår som oförklarligt. Å andra sidan finns ett reglerande förhållningssätt i beskrivningar av "de andras" agerande som, om det är förklarligt - det vill säga ska förstås som rationellt - bygger på en förkastlig moral (jfr Garfinkel 2006[1963]; Watson 2009).

Sammanfattningsvis har det här avsnittet visat hur krisen ger upphov till en abstrakt gemenskap som kan stå som ett handlingskraftigt "vi" som tillsammans kämpar och hanterar motgångar, eller som ett existentiellt "vi" som dör och lever vidare. Detta förhållningssätt kan vara reglerande då det innebär en omdefinition: det egna livet blir meningsfullt på ett nytt sätt. Att använda sig av kulturella resurser, såsom idiom eller en allmän kalender, för meningsskapande kan i stället ses som en anpassning: det uttrycker en basal tillit till nuvarande sätt att förstå tillvaron. Vi har dock också sett hur inringare beskriver sig som exkluderade från den större abstrakta gemenskapen: dessa inringare beskriver sig vara begränsade, hotade och förtryckta av den yttre majoriteten i form av ett oförsiktigt kollektiv som stöds av Sverige och regeringen.

\section{Diskussion}

I den här artikeln visar vi hur vardagslivet i kris begripliggörs av äldre människor i samtal med volontärer på telefonlinjen Äldrelinjen, några månader in i covid-19-pandemin. Vårt huvudresultat är att frånvaron av vardagen såsom den tidigare sett ut skapar eller synliggör utmaningar i sociala relationer, eftersom de inte längre kan tas för givna. Det finns en övergripande problemorientering i inringarnas förhållningssätt till krisen, vilket inte är överraskande. Många inringare beskriver oro, utsatthet och utanförskap (jfr Ayalon, Chasteen, Diehl m.fl. 2020; Rahman \& Jahan 2020). Vår studie ger dock också kunskap om en variation i hur äldre personer förstår sin situation och hur äldres situation kan förstås olika beroende på vilken relation som berörs, något som 
har efterlysts i tidigare forskning (t.ex. Kivi, Hansson \& Bjälkebring 2020). Det finns många exempel på äldre som anpassar sig till den nya vardagen eller beskriver ett nytt förhållningssätt till världen och andra människor (jfr Ayalon Chasteen, Diehl m.fl. 2020).

Liksom den australiensiska studien av covid-19-patienter (Shaban, Nahidi, Sotomayor-Castillo m.fl. 2020) visar vi att krisen skapar behov av att förhålla sig till sociala relationer. Vår studie bidrar genom att förtydliga hur olika slags relationer medför skilda utmaningar och hur dessa hanteras av personer som själva inte har insjuknat. Att denna kris begripliggörs som en kris i inringarnas sociala relationer synliggör den utsatta situation i vilken många av de äldre inringarna befinner sig. Krisen uppenbarar brist (jfr Scott 2018) - på flexibilitet i hemtjänsten, tid och engagemang hos barn och barnbarn, och tillåtelse att vara klagande och behövande i nära relationer. Med Garfinkel (2006[1963]) kan vi förstå utsattheten i personliga relationer som avsaknad av basal tillit: relationer som inte går att byta ut tycks, från inringarnas perspektiv, inte tillåta anpassningar för att hantera krisens utmaningar av vardagslivets ordning.

Anonyma relationer är mer kravlösa eftersom de är möjliga att ersätta: om det saknas gemensamma definitioner av situationen går det att vända sig till andra som kan ge daglig bekräftelse av ens existens, vilket inringarna lyfter fram som viktigt. Krisen visar alltså betydelsen av anonyma relationer vilket stödjer forskning som pekat på hur äldre vinner på relationer med "främlingar" (Fingerman 2009; Torres 2019). I förhållande till dessa resultat är det positivt att många av inringarna hittat relativt säkra sätt att vidmakthålla sådana relationer. Det pekar också på att insatser riktade till äldre, och berättelser om dem i media, behöver inkludera möjliggörandet av anonyma relationer, snarare än att ensidigt fokusera på aspekter av personliga relationer som hotas av krisen, såsom kramar från barnbarn. Ett snävt mediafokus reproducerar äldre personer som en homogen grupp - en bild den här studien utmanar. De anonyma relationernas betydelse i denna studie visar också att även om inringarna kan ses som utsatta i förhållande till personliga relationer så kan de, i likhet med inringare till telefonlinjer generellt, ses som relativt resursstarka på så sätt att de aktivt sökt denna viktiga form av social kontakt (jfr Cook, Randhawa, Large m.fl. 2013).

Relationerna till abstrakta andra under krisen pekar också på hur frånvaron av vardagen, förutom anpassningar (Schatzki 2016), kan innebära en radikal omvärdering av grundläggande vanor eller en ny förståelse av vem personen är i förhållande till ett abstrakt kollektiv (jfr Mead 1981b:341; Lundin 2004). Denna omvärdering kan innebära större närhet till andra, men också mer distans. En gemensam, existentiell kalender (jfr Sacks 1989) eller ett enat vi (Ayalon, Chasteen, Diehl m.fl. 2020) är exempel på vad som utgör en positiv syn på det egna åldrandet (jfr Losada-Baltar, Jiménez-Gonzalo, Gallego-Alberto m.fl. 2020) och vad som skulle kunna ge motståndskraft mot negativa konsekvenser av krisen (jfr Kivi, Hansson \& Bjälkebring 2020). Samtidigt synliggör äldre som saknar tillit till en gemensamt definierad verklighet med ett abstrakt vi att antaganden om ett samhälleligt vi inte inkluderar alla äldre (jfr Turowetz \& Rawls 2020). Även om ett reglerande förhållningssätt till tillit potentiellt skulle kunna generera förändringsarbete när det gäller social rättvisa för äldre i krisen, beskriver 
inringarna inte nya sammanhang för sådana diskussioner. Det finns till exempel inga exempel på forum i politiska organisationer, kyrkor eller pensionärsorganisationer som svarar mot sådana behov. De äldre som beskriver sig som utsatta för ett hotfullt "dom" uttrycker vanmakt och ensamhet snarare än kontakt med andra likasinnade. Kontakten med anonyma andra blir en tröst, men inte en grund för förändringsarbete.

Genom att föra in begrepp om basal och reglerande tillit bidrar vi slutligen till den vardagssociologiska krislitteraturen (se Schatzki 2016) med en förklaring av hur det kommer sig att kriser i människors vardagsliv ibland medför anpassning till den nya situationen och ibland ifrågasättandet av vanor. Krisen kan, om det finns en basal tillit till en gemensam definition av verkligheten, mötas av anpassningar till den nya situationen utan att normer och vanor hotas i grunden. När den basala tilliten till vardagens tolkningar däremot hotas sker ett ifrågasättande av det som tidigare tagits för givet. Denna förklaringsmodell kan användas i vidare forskning i andra sammanhang för att ge förståelse av människors agerande vid kriser. Andra krisstudier (Nevile 2013; Iversen 2019; Sikveland, Kevoe-Feldman \& Stokoe 2019; Stokoe \& Sikveland 2020) har visat hur sociala aktörer i akuta skeenden arbetar för att etablera gemensamma definitioner av situationer för att på så sätt möjliggöra handlande. Vår studie visar hur människor även i den långdragna krisen arbetar för att skapa sammanhang och hur krisens utdragenhet är en del av själva problemet: att etablera en vardag i krisen innebär specifika utmaningar när det gäller tillit eftersom definitioner och normer måste vara långsiktigt hållbara snarare än tillfälliga substitut. Liksom $i$ andra vardagssociologiska studier visar sig därmed tidsmässighet vara viktigt för begripliggörandet, men medan tid i akuta skeenden kan tvinga fram beslut (jfr Nevile 2013) innebär tid $i$ en långdragen kris att nya rutiner behöver etableras. Genom fokus på äldre personer i en ofta utsatt situation, snarare än yrkesutövare, synliggör vi också både skillnader och likheter i hur personernas relationer bidrar till ett särskilt hanterande av krisen.

Artikelns fokus på situerat meningsskapande ger insikt i hjälpsökandeprocesser - på vilket sätt och i vilka sammanhang hjälp söks och erbjuds - vilket är viktigt att förstå i relation till pandemin, då ett växande hälsoproblem är uteblivna vårdbesök och fördröjda behandlingar av andra sjukdomar än covid-19. Vi har dock inte undersökt vilken roll volontärers olika sätt att bemöta inringare - såsom att ge tröst eller erbjuda råd - får för samtalet, vilket är en viktig fråga för vidare forskning. Till exempel behövs kunskap om hur närhet skapas i detta anonyma forum och hur volontärer på olika sätt bemöter inringares klagomål på sin situation. Resultaten kan också användas som utgångspunkt för intervjustudier och enkätundersökningar rörande pandemins effekter i äldres liv, då de identifierade problemen kan fungera som ett underlag för att fånga upp relevanta dimensioner av krisupplevelser för äldre personer. Vår studie av äldre människors villkor under covid-19-pandemin har visat att forskning som uppmärksammar människors vardag behövs för att förstå pandemins sociala konsekvenser. När vardagen står på spel accentueras vikten av det vardagssociologiska perspektivet. 


\section{Tack}

Forskningen har bedrivits med medel från Vetenskapsrådet (Dnr: 2019-02575). Vi vill rikta ett stort tack till de anonyma granskarna som har hjälp oss att förbättra artikeln med sin noggranna och konstruktiva kritik. En tidigare version av artikeln har presenterats i Välfärdsgruppen, Sociologiska institutionen, Uppsala universitet, och vi vill tacka deltagarna för hjälpsamma kommentarer.

\section{Referenser}

Armitage, R. \& L.B. Nellums (2020) "COVID-19 and the consequences of isolating the elderly", The Lancet Public Health 5 (5):e256. https://doi.org/10.1016/S24682667(20)30061-X

Ayalon, L., A. Chasteen, M. Diehl, B. Levy, S.D. Neupert, K. Rothermund, C. TeschRömer \& H.W. Wahl (2020) "Aging in times of the COVID-19 pandemic. Avoiding ageism and fostering intergenerational solidarity", The Journals of Gerontology: Series B 76 (2): e49-e52. https://doi.org/10.1093/geronb/gbaa051

Braun, V. \& V. Clarke (2006) "Using thematic analysis in psychology", Qualitative Research in Psychology 3 (2):77-101. https://doi.org/10.1191/1478088706qp063oa

Brown, P. (2020) "Studying COVID-19 in light of critical approaches to risk and uncertainty. Research pathways, conceptual tools, and some magic from Mary Douglas", Health, Risk \& Society 22 (1):1-14. https://doi.org/10.1080/13698575. 2020.1745508

Chan, S.S.M., H.F.K Chiu, L.C.W. Lam, V.P.Y. Leung \& Y. Conwell (2006) "Elderly suicide and the 2003 SARS epidemic in Hong Kong", International Journal of Geriatric Psychiatry 21 (2):113-118. https://doi.org/10.1002/gps.1432

Clifton, J. (2015) "Using identities-in-talk as a persuasive strategy. The case of police crisis negotiations with Mohamed Merah, a self-proclaimed Mujahedin”, 179-200 i R. Săftoiu, M.-I. Neagu \& S. Măda (red.) Persuasive games in political and professional dialogue. Amsterdam: John Benjamins. https://doi.org/10.1075/ds.26.09cli

Cook, E.J., G. Randhawa, S. Large, A. Guppy \& A. Chater, A. (2013). ”Who uses telephone based helplines? Relating deprivation indices to users of NHS Direct", Health Policy and Technology 2 (2): 69-74. https://doi.org/10.1016/j.hlpt.2013.03.002

Creswell, J.W. \& D.L. Miller (2000) "Determining validity in qualitative inquiry", Theory into Practice 39 (3):124-130. https://doi.org/10.1207/s15430421tip3903_2

Cullen, W., G. Gulati \& B.D. Kelly (2020) "Mental health in the COVID-19 pandemic", QJM: An International Journal of Medicine 113 (5):311-312. https://doi. org/10.1093/qjmed/hcaa110

De Rycker, A. \& Z. Mohd Don (2013) Discourse and crisis. Critical perspectives. Amsterdam: John Benjamins. https://doi.org/10.1075/dapsac.52

Fingerman, K.L. (2009) "Consequential strangers and peripheral ties. The importance of unimportant relationships", Journal of Family Theory \& Review 1 (2):69-86. https://doi.org/10.1111/j.1756-2589.2009.00010.x 
Flinkfeldt, M. (2020) "Managing moral dimensions of financial hardship. Housing allowance claimants' orientations to 'deservingness' at the Swedish Social Insurance Agency". Opublicerat manuskript.

Folkhälsomyndigheten (2020a) Beteende, oro och informationsbehov. Genomförda och pågående undersökningar under covid-19. Solna \& Östersund: Folkhälsomyndigheten.

Folkhälsomyndigheten (2020b) Hälsorapport. Psykisk hälsa under coronapandemin. Solna \& Östersund: Folkhälsomyndigheten.

Garfinkel, H. (2006[1963]) "A conception of, and experiments with, 'trust' as a condition for stable concerted actions", 370-381 i J. O'Brien (red.) The production of reality. Essays and readings on social interaction, fjärde upplagan. Thousand Oaks: Pine Forge Press.

Garfinkel, H (1967) Studies in ethnomethodology. Englewood Cliffs: Prentice-Hall.

Garfinkel, H (1988) "Evidence for locally produced, naturally accountable phenomena of order, logic, reason, meaning, method, etc. in and as of the essential quiddity of immortal ordinary society, (I of IV). An announcement of studies", Sociological Theory 6 (1):103-109. https://doi.org/10.2307/201918

Gibson, D.R. (2011) "Avoiding catastrophe. The interactional production of possibility during the Cuban missile crisis", American Journal of Sociology 117 (2):361-419. https://doi.org/10.1086/661761

Giustini, D. (2020) "Theorising - crises? What crises? Conceptualising breakdowns in practice theory", The European Sociologist 45 (1).

Iversen, C. (2019) "Att erbjuda ett annat perspektiv. Bemötande på en telefonlinje med fokus på självmord”. Paper presenterat vid 12:e nationella suicidpreventiva konferensen, Norrköping.

Jia, Y., O. Chen, Z. Xiao, J. Xiao, J. Bian, H. Jia (2020) "Nurses' ethical challenges caring for people with COVID-19. A qualitative study", Nursing Ethics 28 (1):33-45. https://doi.org/10.1177/0969733020944453

Kivi, M., I. Hansson \& P. Bjälkebring (2020) "Up and about. Older adults' wellbeing during the COVID-19 pandemic in a Swedish longitudinal study", Journals of Gerontology. Social Sciences 76 (2): e4-e9. https://doi.org/10.1093/geronb/gbaa084

Le Couteur, D.G., R.M. Anderson \& A.B. Newman (2020) "COVID-19 through the lens of gerontology", Journals of Geronotology. Medical Sciences 75 (9):119-120. https://doi.org/10.1093/gerona/glaa077

Leung, C. (2020) "Risk factors for predicting mortality in elderly patients with COVID-19: a review of clinical data in China", Mechanisms of Ageing and Development 188:111255. https://doi.org/10.1016/j.mad.2020.111255

Liu, K., Y. Chen, R. Lin \& K. Han (2020) "Clinical features of COVID-19 in elderly patients. A comparison with young and middle-aged patients", Journal of Infection 80 (6):4-18. https://doi.org/10.1016/j.jinf.2020.03.005

Losada-Baltar, A., L. Jiménez-Gonzalo, L. Gallego-Alberto, M.D.S. Pedroso-Chaparro, J. Fernandes-Pires \& M. Márquez-González (2020) "'We are staying at home’. Association of self-perceptions of aging, personal and family resources and loneliness 
with psychological distress during the lock-down period of COVID-19", The Journals of Gerontology: Series B 76 (2):e10-e16 . https://doi.org/10.1093/geronb/gbaa048

Lundin, E. (2004) Motstånd och kreativitet. George Herbert Meads bidrag till aktörstrukturdebatten. Stehag: Symposion.

Mak, I.W., C.M. Chu, P.C. Pan, M.G. Yiu \& V.L. Chan (2009) "Long-term psychiatric morbidities among SARS survivors", General Hospital Psychiatry 31 (4):318-326. https://doi.org/10.1016/j.genhosppsych.2009.03.001

Mead, G.H. (1981a[1910]) "Social consciousness and the consciousness of meaning", 123-133 i A. Reck (red.) Selected writings. George Herbert Mead, Chicago: The University of Chicago Press.

Mead, G.H. (1981b[1929]) "A pragmatic theory of truth", 320-344 i A. Reck (red.) Selected writings. George Herbert Mead, Chicago: The University of Chicago Press.

Meng, H., Y. Xu, J. Dai, Y. Zhang, B. Liu \& H. Yang (2020) "Analyze the psychological impact of COVID-19 among the elderly population in China and make corresponding suggestions", Psychiatry Research 289:112983. https://doi. org/10.1016/j.psychres.2020.112983

Nevile, M. (2013) "Collaboration in crisis. Pursuing perception through multiple descriptions (how friendly vehicles became damn rocket launchers)", 159-183 i A. De Rycker \& Z. Mohd Don (red.). Discourse and crisis. Critical perspectives. Amsterdam: John Benjamins. https://doi.org/10.1075/dapsac.52

Persson, M. \& E. Thunman (2011) "George Herbert Mead och motståndet", 47-72 i J. Stier \& J. Lindblom (red.) Det socialpsykologiska perspektivet. Lund: Studentlitteratur.

Pirkis, J., A. Middleton, B. Bassilios, M. Harris, M.J. Spittal, I. Fedszyn, P. Chondros \& J. Gunn (2016) "Frequent callers to telephone helplines. New evidence and a new service model", International Journal of Mental Health Systems 10:43. https:// doi.org/10.1186/s13033-016-0076-4

Potter, J. (2002) "Two kinds of natural", Discourse Studies 4 (4):539-542. https://doi. org/10.1177/14614456020040040901

Qiu, J., B. Shen, M. Zhao, Z. Wang, B. Xie \& Y. Xu (2020) "A nationwide survey of psychological distress among Chinese people in the COVID-19 epidemic. Implications and policy recommendations", General Psychiatry 33 (2):e100213. https://doi. org/10.1136/gpsych-2020-100213

Rahman, A. \& Y. Jahan (2020) "Defining a 'risk group' and ageism in the era of COVID-19", Journal of Loss and Trauma 25 (8):631-634. https://doi.org/10.1080/ 15325024.2020 .1757993

Redmalm, D. (2020) "Discipline and puppies. The powers of pet keeping", International Journal of Sociology and Social Policy. Nätpublicering. https:/doi.org/10.1108/ IJSSP-08-2019-0162

Sacks, H. (1989). "Lecture five. Suicide as a device for discovering if anybody cares", Human Studies 12 (3-4):261-270. https://doi.org/10.1007/bf00142770

Scott, S. (2018) "A sociology of nothing. Understanding the unmarked", Sociology 52 (1):3-19. https://doi.org/10.1177/0038038517690681 
Schatzki, T. (2016) "Crises and adjustments in ongoing life", Österreichische Zeitschrift für Soziologie 41:17-33. https://doi.org/10.1007/s11614-016-0204-z

Shaban, R.Z., S. Nahidi, C. Sotomayor-Castillo, C. Li, N. Gilroy, M.V.N. O’Sullivan, T.C. Sorrell, E. White, K. Hackett \& S. Bag (2020) "SARS-CoV-2 infection and COVID-19. The lived experience and perceptions of patients in isolation and care in an Australian healthcare setting", American Journal of Infection Control 48 (12):1445-1450. https://doi.org/10.1016/j.ajic.2020.08.032

Sher, L. (2020) "The impact of the COVID-19 pandemic on suicide rates", QJM: An International Journal of Medicine 113 (10):707-712. https://doi.org/10.1093/qjmed/ hcaa202

Sikveland, R.O., H. Kevoe-Feldman \& E. Stokoe (2019) "Overcoming suicidal persons' resistance using productive communicative challenges during police crisis negotiations", Applied Linguistics 41 (4):533-551. https://doi.org/10.1093/applin/ amy065

Stokoe, E. \& R.O. Sikveland (2020) "The backstage work negotiators do when communicating with persons in crisis", Journal of Sociolinguistics 24 (2):185-208. https:// doi.org/10.1111/josl.12347

Sun N., L. Wei, S. Shi, D. Jiao, R. Song, L. Ma, H. Wang, C. Wang, Z. Wang, Y. You, S. Liu \& H. Wang (2020) "A qualitative study on the psychological experience of caregivers of COVID-19 patients", American Journal of Infection Control 48 (6):592-598. https://doi.org/10.1016/j.ajic.2020.03.018

Svetlova, E. (2012) "Talking about the crisis. Performance of forecasting in financial markets", Culture and Organization 18 (2):155-169. https://doi.org/10.1080/14759 551.2011.636618

Torres, S. (2019) "Aging alone, gossiping together. Older adults' talk as social glue", The Journals of Gerontology 74 (8):1474-1482. https://doi.org/10.1093/geronb/gby154

Turowetz, J. \& A. Warfield Rawls (2020) "The development of Garfinkel's 'trust' argument from 1947 to 1967. Demonstrating how inequality disrupts sense and self-making", Journal of Classical Sociology 21 (1):3-37. https://doi. org/10.1177/1468795X19894423

Vaismoradi M., H. Turunen \& T. Bondas (2013) "Content analysis and thematic analysis. Implications for conducting a qualitative descriptive study", Nursing \& Health Sciences 15 (3):398-405. https://doi.org/10.1111/nhs.12048

Watson, R. (2009) "Constituitive practices and Garfinkel's notion of trust. Revisited", Journal of Classical Sociology 9 (4):475-499. https://doi. org/10.1177/1468795X09344453

Xiang, Y.-T., L. Yang, W. Li, L. Zhang, Q. Zhang, T. Cheung \& C.H. Ng (2020) "Timely mental health care for the 2019 novel coronavirus outbreak is urgently needed", The Lancet. Psychiatry 7 (3):228-229. https://doi.org/10.1016/S2215-0366(20)30046-8 Yip, P.S.F., Y.T. Cheung, P.H. Chau \& Y.W. Law (2010) "The impact of epidemic outbreak. The case of severe acute respiratory syndrome (SARS) and suicide among older adults in Hong Kong", Crisis. The Journal of Crisis Intervention and Suicide Prevention 31 (2):86-92. https://doi.org/10.1027/0227-5910/a000015 


\section{Författarpresentationer}

Clara Iversen är docent i sociologi och lektor i socialt arbete vid Uppsala universitet. Iversens forskning handlar om hur personer hanterar intersubjektivitet i institutionell interaktion. För närvarande forskar hon om interaktion på hjälplinjer samt mellan människor och robotar.

David Redmalm är lektor i sociologi vid Mälardalens högskola. Han forskar om relationer mellan människor och andra djur, och hur föreställningar om det mänskliga och det djuriska gör avtryck i socialt liv och sociologisk teori.

Marie Flinkfeldt disputerade i sociologi vid Uppsala universitet 2016. Hon är för närvarande biträdande lektor i socialt arbete vid Uppsala universitet. Hennes forskning rör framför allt interaktion inom olika välfärdsstatliga organisationer, med ett särskilt fokus på kategorisering och bemötande.

Marcus Persson är docent i sociologi vid Linköpings universitet. Han forskar om användningen av ny teknologi och social transformation. För närvarande är han involverad i flera forskningsprojekt om användningen av robotar i arbetslivet och dess påverkan på relationer, arbetsmiljö och profession.

\section{Kontaktuppgifter}

Clara Iversen

Sociologiska institutionen

Uppsala universitet, Box 624, 75126 Uppsala

clara.iversen@soc.uu.se 